\title{
Palladium-Catalyzed Cyanation of Aryl Bromides Promoted by Low-level Organotin Compounds
}

\author{
Chunhua Yang* and J. Michael Williams
}

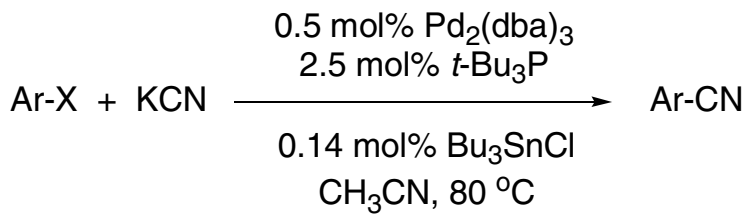

General Considerations: All reactions were carried out under a nitrogen atmosphere in dried glassware. All aryl halides, heteroaryl halides and the aryl triflate were purchased from commercial sources and were used without further purification. Potassium cyanide, tri- $n$-butyltin chloride and tris(dibenzylideneacetone) dipalladium(0) were purchased from Aldrich Chemical Co. and were used directly. Acetonitrile was purchased from Fisher Scientific Company and contained less than $80 \mu \mathrm{g} / \mathrm{mL}$ water. Tri-tertbutylphosphine (10 wt\% in hexanes) and Xantphos were purchased from Strem Chemicals. Tri- $n$-butyltin chloride solution $(14 \mu \mathrm{L} / \mathrm{mL})$ was prepared by addition of 0.14 $\mathrm{mL}$ of tri- $n$-butyltin chloride into $10 \mathrm{~mL}$ of heptane. Conversion was determined by HPLC assay. ${ }^{1} \mathrm{H}$ NMR and ${ }^{13} \mathrm{C}$ NMR were obtained with a Bruker DPX-400 in $\mathrm{CDCl}_{3}$.

\section{General Procedures for table 1 compounds:}

\section{Condition a:}

Entry 1

To a dry $50 \mathrm{~mL}$ flask was added $\mathrm{KCN}(0.8 \mathrm{~g}, 12 \mathrm{mmol})$, acetonitrile $(7.5 \mathrm{~mL})$ and 1bromonaphthalene $(1.1 \mathrm{~mL}, 8 \mathrm{mmol})$. The suspension was degassed three times (vacuum / nitrogen), and then a solution of $\mathrm{Bu}_{3} \mathrm{SnCl}$ in heptane $(0.24 \mathrm{~mL}, 0.011 \mathrm{mmol}), t-\mathrm{Bu}_{3} \mathrm{P}(10$ wt $\%$ in hexanes, $0.63 \mathrm{~mL}, 0.2 \mathrm{mmol})$ and $\mathrm{Pd}_{2}(\mathrm{dba})_{3}(38 \mathrm{mg}, 0.04 \mathrm{mmol})$ were added. The suspension was degassed three times and stirred at ambient temperature for $30 \mathrm{~min}$. The mixture was degassed again, and then heated at $80{ }^{\circ} \mathrm{C}$ for $17 \mathrm{~h}$. Reaction conversion was determined by HPLC. The reaction mixture was diluted with ethyl acetate or MTBE $(20 \mathrm{~mL})$, and result was washed with water $(10 \mathrm{~mL})$ twice. The organic solution was dried with $\mathrm{Na}_{2} \mathrm{SO}_{4}$ and concentrated. The residue was purified with a silica gel column (hexanes/ethyl acetate 8/1) to afford the title compound with a yield of $97 \%$.

${ }^{1} \mathrm{H}$ NMR: $\delta 8.26(d d, J=8.4 \mathrm{~Hz}, 0.8 \mathrm{~Hz}, 1 \mathrm{H}), 8.10(d, J=8.4 \mathrm{~Hz}, 1 \mathrm{H}), 7.96-7.92(m, 2$

$\mathrm{H}), 7.74-7.70(m, 1 \mathrm{H}), 7.66-7.62(m, 1 \mathrm{H}), 7.56-7.53(m, 1 \mathrm{H})$.

${ }^{13} \mathrm{C}$ NMR $\delta$ 133.3, 133.0, 132.7, 132.5, 128.7, 128.7, 127.6, 125.3, 125.0, 117.9, 110.3. 
Entry 2

The residue was purified with a silica gel column (hexanes/MTBE 4/1) to afford the title compound with a yield of $90 \%$.

${ }^{1} \mathrm{H}$ NMR: $\delta$ 7.68-7.64 (m, $\left.2 \mathrm{H}\right), 7.64-7.60(m, 1 \mathrm{H}), 7.51-7.27(m, 2 \mathrm{H})$.

${ }^{13} \mathrm{C}$ NMR $\delta$ 132.8, 132.2, 129.2, 118.9, 112.6.

Entry 3

The residue was purified with a silica gel column (hexanes/ethyl acetate 8/1) to afford the title compound with a yield of $90 \%$.

${ }^{1} \mathrm{H}$ NMR: $\delta 7.56(d, J=8.2 \mathrm{~Hz}, 2 \mathrm{H}), 7.27(d, J=8.2 \mathrm{~Hz}, 2 \mathrm{H}), 2.43(s, 3 \mathrm{H})$.

${ }^{13} \mathrm{C}$ NMR $\delta$ 143.7, 132.1, 129.9, 119.2, 109.4, 21.9.

Entry 4

The residue was purified with a silica gel column (hexanes/ethyl acetate 8/1) to afford the title compound with a yield of $93 \%$.

${ }^{1} \mathrm{H}$ NMR: $\delta$ 7.75-7.69 ( $\left.m, 4 \mathrm{H}\right)$, 7.62-7.59 ( $\left.m, 2 \mathrm{H}\right)$, 7.52-7.48 (m, $\left.2 \mathrm{H}\right)$, 7.46-7.27 ( $m, 1$

$\mathrm{H})$

${ }^{13}$ C NMR $\delta 145.6,139.1,132.5,129.0,128.6,127.6,127.1,118.8,110.8$.

Entry 5

The residue was purified with a silica gel column (hexanes/ethyl acetate 8/1) to afford the title compound with a yield of $54 \%$.

${ }^{1} \mathrm{H}$ NMR: $\delta$ 7.71-7.67 ( $\left.m, 2 \mathrm{H}\right), 7.19-7.17(m, 2 \mathrm{H})$.

${ }^{13}$ C NMR: $\delta 165.1(d, J=256.4 \mathrm{~Hz}), 134.7(d, J=9.5 \mathrm{~Hz}), 118.0,116.9(d, J=22.7 \mathrm{~Hz})$, $117.7(d, J=3.5 \mathrm{~Hz})$.

Entry 6

The residue was purified with a silica gel column (hexanes/MTBE 8/1) to afford the title compound with a yield of $81 \%$.

${ }^{1} \mathrm{H}$ NMR: $\delta$ 7.92-7.81 $(m, 4 \mathrm{H})$.

${ }^{13} \mathrm{C}$ NMR $\delta 134.6(q, J=33.6 \mathrm{~Hz}), 132.7,126.2(q, J=3.7 \mathrm{~Hz}), 123.1(q, J=273.0 \mathrm{~Hz})$, 117.4, 116.1 .

\section{Entry 7}

The residue was purified with a silica gel column (hexanes/ethyl acetate 8/1) to afford the title compound with a yield of $93 \%$.

${ }^{1} \mathrm{H}$ NMR: $\delta 8.10(d, J=8.5 \mathrm{~Hz}, 2 \mathrm{H}), 7.78(d, J=8.4 \mathrm{~Hz}, 2 \mathrm{H}), 2.65(s, 3 \mathrm{H})$.

${ }^{13} \mathrm{C}$ NMR $\delta 196.5,140.0,132.6,128.7,117.9,116.5,26.8$.

\section{Entry 8}

The residue was purified with a silica gel column (hexanes/MTBE 8/1) to afford the title compound with a yield of $91 \%$.

${ }^{1} \mathrm{H}$ NMR: $\delta 8.15(d, J=8.4,2 \mathrm{H}), 7.75(d, J=8.6,2 \mathrm{H}), 4.43(q, J=7.2,2 \mathrm{H}), 1.42(t, 7.2$, $3 \mathrm{H})$. 
${ }^{13} \mathrm{C}$ NMR $\delta$ 165.0, 134.4, 132.2, 130.1, 118.0, 116.4, 61.9, 14.3.

Entry 9

The residue was purified with a silica gel column (hexanes/MTBE 8/1) to afford the title compound with a yield of $50 \%$.

${ }^{1} \mathrm{H}$ NMR: $\delta$ 7.59-7.57 ( $\left.m, 2 \mathrm{H}\right), 6.96-6.94(m, 2 \mathrm{H}), 3.86(s, 3 \mathrm{H})$.

${ }^{13} \mathrm{C}$ NMR $\delta 162.9,134.0,119.2,114.8,104.1,55.6$.

Entry 12

The reaction was carried out at $22{ }^{\circ} \mathrm{C}$ for $3 \mathrm{~h}$. The residue was purified with a silica gel column (hexanes/MTBE 8/1) to afford the title compound with a yield of $96 \%$.

${ }^{1} \mathrm{H}$ NMR: $\delta 7.56(d, J=8.2 \mathrm{~Hz}, 2 \mathrm{H}), 7.27(d, J=8.2 \mathrm{~Hz}, 2 \mathrm{H}), 2.43(s, 3 \mathrm{H})$.

${ }^{13} \mathrm{C}$ NMR $\delta$ 143.7, 132.1, 129.9, 119.2, 109.4, 21.9.

Entry 13

The residue was purified with a silica gel column (hexanes/MTBE 8/1) to afford the title compound with a yield of $92 \%$.

${ }^{1} \mathrm{H}$ NMR: $\delta 7.65(d d, J=1.9 \mathrm{~Hz}, 1.8 \mathrm{~Hz}, 1 \mathrm{H}), 7.60(d d d, J=8.1 \mathrm{~Hz}, 2.0 \mathrm{~Hz}, 1.1 \mathrm{~Hz}, 1$

$\mathrm{H}), 7.56(d d d, J=7.8 \mathrm{~Hz}, 1.4 \mathrm{~Hz}, 1.4 \mathrm{~Hz}, 1 \mathrm{H}), 7.42(d d, J=7.8 \mathrm{~Hz}, 7.8$

$\mathrm{Hz}, 1 \mathrm{H})$.

${ }^{13}$ C NMR: $\delta$ 135.4, 133.3, 132.0, 130.5, 130.3, 117.5, 114.1 .

Entry 14

The residue was purified with a silica gel column (hexanes/ethyl acetate $2 / 1$ ) to afford the title compound with a yield of $89 \%$.

${ }^{1} \mathrm{H}$ NMR: $\delta 7.67(s, 1 \mathrm{H}), 7.61-7.55(m, 2 \mathrm{H}), 7.46(d d, J=7.7 \mathrm{~Hz}, 7.6 \mathrm{~Hz}, 1 \mathrm{H}), 4.74(s$,

$2 \mathrm{H}), 2.22(b r, 1 \mathrm{H})$.

${ }^{13}$ C NMR $\delta 142.4,131.1,131.0,130.2,129.3,118.8,112.4,63.9$.

Entry 15

The amount of $\mathrm{Bu}_{3} \mathrm{SnCl}$ solution was reduced to $0.12 \mathrm{~mL}$. The residue was purified with a silica gel column (hexanes/MTBE 8/1) to afford the title compound with a yield of $90 \%$.

\section{Condition b:}

Entry 17

To a dry $50 \mathrm{~mL}$ flask was added $\mathrm{KCN}(0.8 \mathrm{~g}, 12 \mathrm{mmol})$, acetonitrile $(7.5 \mathrm{~mL})$ and 3bromopyridine $(0.78 \mathrm{~mL}, 8 \mathrm{mmol})$. The suspension was degassed three times (vacuum / nitrogen), and then a solution of $\mathrm{Bu}_{3} \mathrm{SnCl}$ in heptane $(0.43 \mathrm{~mL}, 0.021 \mathrm{mmol})$, XANTPHOS (23 mg, $0.04 \mathrm{mmol})$ and $\mathrm{Pd}_{2}(\mathrm{dba})_{3}(38 \mathrm{mg}, 0.04 \mathrm{mmol})$ were added. The suspension was degassed three times and stirred at ambient temperature for $30 \mathrm{~min}$. The mixture was degassed again, and then heated at $80^{\circ} \mathrm{C}$ for $17 \mathrm{~h}$. Reaction conversion was determined by HPLC. The reaction mixture was diluted with ethyl acetate or MTBE (20 $\mathrm{mL})$, and result was washed with water $(10 \mathrm{~mL})$ twice. The organic solution was dried 
with $\mathrm{Na}_{2} \mathrm{SO}_{4}$ and concentrated. The residue was purified with a silica gel column (hexanes/MTBE 8/1) to afford the title compound with a yield of $93 \%$.

${ }^{1} \mathrm{H}$ NMR: $\delta 8.90(d d J=2.0 \mathrm{~Hz}, 0.7 \mathrm{~Hz}, 1 \mathrm{H}), 8.83(d d, J=5.0 \mathrm{~Hz}, 1.7 \mathrm{~Hz}, 1 \mathrm{H}), 7.98$

$(d d d, J=8.1 \mathrm{~Hz}, 1.7 \mathrm{~Hz}, 1.7 \mathrm{~Hz}, 1 \mathrm{H}), 7.45(d d d, J=8.0 \mathrm{~Hz}, 4.0 \mathrm{~Hz}, 0.7$

$\mathrm{Hz}, 1 \mathrm{H})$.

${ }^{13} \mathrm{C}$ NMR $\delta$ 153.0, 152.5, 139.2, 123.6, 116.5, 110.2.

Entry 10

The residue was purified with a silica gel column (hexanes/MTBE 8/1) to afford the title compound with a yield of $78 \%$.

${ }^{1} \mathrm{H}$ NMR: $\delta$ 8.38-8.36 (m, $\left.2 \mathrm{H}\right), 7.91-7.89(m, 2 \mathrm{H})$.

${ }^{13} \mathrm{C}$ NMR $\delta 133.5,124.3,118.4,116.8$.

Entry 11

The residue was purified with a silica gel column (hexanes/MTBE 8/1) to afford the title compound with a yield of $88 \%$.

${ }^{1} \mathrm{H}$ NMR: $\delta$ 8.38-8.36 ( $\left.m, 2 \mathrm{H}\right), 7.91-7.89(m, 2 \mathrm{H})$.

${ }^{13} \mathrm{C}$ NMR $\delta$ 133.5, 124.3, 118.4, 116.8 .

Entry 16

The amount of $\mathrm{Bu}_{3} \mathrm{SnCl}$ solution was reduced to $0.24 \mathrm{~mL}$. DPPF (23 $\mathrm{mg}$ ) was used as a catalyst ligand. The residue was purified with a silica gel column (hexanes/ethyl acetate $2 / 1)$ to afford the title compound with a yield of $88 \%$.

${ }^{1} \mathrm{H}$ NMR: $\delta 8.72(\mathrm{dt}, \mathrm{J}=4.8 \mathrm{~Hz}, 1 \mathrm{H}), 7.85(\mathrm{dt}, \mathrm{J}=8.0 \mathrm{~Hz}, 1.8 \mathrm{~Hz}, 1 \mathrm{H}), 7.70(\mathrm{dt}, \mathrm{J}=7.8$ $\mathrm{Hz}, 1 \mathrm{H}$ ), 7.54 (ddd, J = 7.8 Hz, $4.8 \mathrm{~Hz}, 3.8 \mathrm{~Hz}, 1 \mathrm{H}$ )

${ }^{13} \mathrm{C}$ NMR $\delta$ 151.2, 137.1, 134.1, 128.6, 127.0, 117.2.

Entry 18

The reaction was carried out at $22{ }^{\circ} \mathrm{C}$ for $3 \mathrm{~h}$. The residue was purified with a silica gel column (hexanes/ethyl acetate 8/1) to afford the title compound with a yield of $95 \%$.

${ }^{1} \mathrm{H}$ NMR: $\delta 8.90(d d J=2.0 \mathrm{~Hz}, 0.7 \mathrm{~Hz}, 1 \mathrm{H}), 8.83(d d, J=5.0 \mathrm{~Hz}, 1.7 \mathrm{~Hz}, 1 \mathrm{H}), 7.98$

$(d d d, J=8.1 \mathrm{~Hz}, 1.7 \mathrm{~Hz}, 1.7 \mathrm{~Hz}, 1 \mathrm{H}), 7.45(d d d, J=8.0 \mathrm{~Hz}, 4.0 \mathrm{~Hz}, 0.7$

$\mathrm{Hz}, 1 \mathrm{H})$.

${ }^{13} \mathrm{C}$ NMR $\delta$ 153.0, 152.5, 139.2, 123.6, 116.5, 110.2.

Entry 19

The residue was purified with a silica gel column (hexanes/ethyl acetate 8/1) to afford the title compound with a yield of $96 \%$.

${ }^{1} \mathrm{H}$ NMR: $\delta 9.03(d, J=1.7 \mathrm{~Hz}, 1 \mathrm{H}), 8.53(d, J=2.0 \mathrm{~Hz}, 1 \mathrm{H}), 8.17(d, J=8.9 \mathrm{~Hz}, 1 \mathrm{H})$. $7.91-7.88(\mathrm{~m}, 2 \mathrm{H}), 7.69(d t, J=8.0 \mathrm{~Hz}, 1.1 \mathrm{~Hz}, 1 \mathrm{H})$

${ }^{13} \mathrm{C}$ NMR $\delta$ 149.8, 148.9, 141.5, 132.8, 129.9, 128.5, 128.3, 126.3, 117.1, 106.7,

NMR studies: 
To a NMR tube was added $\mathrm{CD}_{3} \mathrm{CN}(0.8 \mathrm{~mL}), \mathrm{Bu}_{3} \mathrm{SnCl}(54 \mu \mathrm{L})$. After recorded ${ }^{1} \mathrm{H}$ and ${ }^{13} \mathrm{C}$ NMR spectra, $\mathrm{KCN}(13 \mathrm{mg})$ was added, and then sonicated for 30 seconds. ${ }^{1} \mathrm{H}$ and ${ }^{13} \mathrm{C}$ NMR spectra was recorded.

${ }^{1} \mathrm{H}$ and ${ }^{13} \mathrm{C}$ NMR spectra of $\mathrm{Bu}_{3} \mathrm{SnCN}(60 \mathrm{mg})$ and $\mathrm{Bu}_{3} \mathrm{SnCN}$ with $\mathrm{KCN}(13 \mathrm{mg})$ were separately recorded in $\mathrm{CD}_{3} \mathrm{CN}(0.8 \mathrm{~mL})$. 